\title{
The impact of Servant Leadership on Organizational Trust: The Mediating Role of Organizational Culture
}

\author{
Bader Ali Almutairi, \\ Mohammad Abd-alkarim Alraggad, \\ Mohammad Khasawneh, \\ The World Islamic Sciences and Education University, Jordan
}

Doi:10.19044/esj.2020.v16n16p49 ～URL:http://dx.doi.org/10.19044/esj.2020.v16n16p49

\begin{abstract}
This study aims to examine the impact of servant leadership on organizational trust and mediating role of organizational culture for the mentioned relationship for employees in the Kuwaiti Ministry of Higher Education. A survey questionnaire was used as the main instrument for data collection. A total of 285 questionnaires were distributed among the Kuwaiti Ministry of Higher Education employees. In total, 248 valid questionnaires to analysis were returned equivalent to $87 \%$ response rate. Data analysis was conducted with the help of PLS-SEM to determine the level of relationships among servant leadership, organizational trust, and organizational culture. According to the obtained findings, there is a positive impact of servant leadership on organizational trust, and organizational culture has a partially mediated role in the relationship between servant leadership and organizational trust. The study findings motivate future studies to carry out studies of the same caliber in other sectors to obtain different perspectives.
\end{abstract}

Keywords: Servant leadership, Organizational Trust, Organizational Culture

\section{Introduction}

Nowadays, the importance of organizational trust has increased, due to the increasing environmental and economic changes, increasing need for flexibility and cooperation, and high level of confidence towards the organization and employees (Kurnaz, 2018). Although there are many definitions for organizational trust, these definitions referring to trust-building are not sufficient as a quantity and content. The main reason is the continuous change that occurs in organizational performance and the human factor (Gider, 2010). Organizational trust is a trust that is reflected in both individuals and organizations (Shockley-Zalabak et al., 2000). According to Dennis (2004), organizational trust is a multi-level concept concerned with interactions 
between different levels of colleagues, teams, and employees within an organization. However, previous literature has at most concentrated on trust for employees in the top and middle management, neglecting trust for employees in lower management (Ferres, Connell \& Travaglione, 2004; Vanhala, Heilmann \& Salminen, 2016).

The importance of trust in higher education institutions is considered significant (Chen, 2017). In studies, organizational trust is known as a fundamental factor and the researchers believe that the organizations should create trust in their employees (Vanhala, Heilmann \& Salminen, 2016). Therefore, the leader's behavior is thus more important than anyone else in determining the level of trust that exists within a group or organization (Blanchard, 2018). Moreover, trust between management and employees will have a large impact on the quality of public management. Thus, the shortage of trust in higher education is one of the main factors lead to uninventive and indifferent employees. It seems that servant leadership is an appropriate solution to address this problem in of higher education institutions because trust is one of the indicators of servant leadership (Eva, Robin, Sendjaya, Dierendonck, \& Liden, 2019).

In recent years the understandings of servant leadership theory have increased (Gandolfi, Stone, \& Deno, 2017). Most of the researchers indicate that servant leadership theory can be the root of many researches about organizational management and leadership (Alown, Mohamad \& Karim, 2020; Lemoine, Hartnell \& Leroy, 2019). Matteson and Irving (2006) believe the servant leader is a person that insisted on his follower's benefits compare to personal benefit. On the other hand, trust in work has not yet received systematic attention despite acknowledging its importance (Balkan, Serin \& Soran, 2014). Salama (2018) indicated that organizational culture contributes to shaping the identity of the organization and developing the teamwork adaptation with internal and external impacts that may occur in the work environment. However, there is a lack of studies about the impact of organizational culture on institutions of Higher education (Indiya, Obura, \& Mise, 2018). In addition, previous studies have examined the relationship between leadership and performance as well as the relationship between organizational culture and performance (Belias \& Koustelios, 2014), but it did not attend to examine the relationship between leadership and organizational culture.

Ministry of Higher Education in Kuwait general is exposed to several problems related to human resources such as the lack of qualified workforce, the high rate of employee turnover, and employee stress (El Mallakh, 2019). Moreover, related to their core operational processes such as seasonality, and high customers' expectations (Reid \& Sanders, 2019). Therefore, this study aims to examine the impact of servant leadership on organizational trust, by 
mediating role of organizational culture for employees in the Kuwaiti Ministry of Higher Education using a quantitative approach.

\section{Literature Review and Development Hypotheses}

\subsection{Servant Leadership}

Servant leadership is anchored in the human drive to bond with others and contribute to the betterment of the society. An emphasis on service motivation, as demonstrated by empowering and developing employees with empathy and humility, differentiates servant leadership from other leadership frameworks (Harwiki, 2016). Kiker, Callahan and Kiker (2019) indicated that servant leaders arouse team potency and team effectiveness as servant leaders enhance the organization's goals, making the success of the organization the subject of focus rather than emphasizing organizational objectives as is true of other forms of leadership.

Honesty and integrity are essential factors a good leader, based on the history of leadership, where these values can cause the creation of people trust and organizational trust, thus eaders who have honesty can inspiration trust to others (Cashman, 2017). Moreover, the trust climate derived from the leader can establish a good organizational culture and facilitate the participation (Aburumman, Salleh, Omar \& Abadi, 2020). Researchers indicate that servant leadership has direct effect with organizational trust (e.g. Nyhan, 2000; Sendjaya \& Sarros, 2002; Rezaei et al., 2012). Researchers also indicate that servant leadership has direct effect with organizational culture (e.g. Harwiki, 2016; Setyaningrum, 2017; Sihombing et al., 2018).

\subsection{Organizational Trust}

Pierce and Newstrom (2003) define trust as the belief to achieve dreams and expectations that are dependent on others. Asencio and Mujkic (2016) believes that employees trust their leaders, who want to fulfill job to do. In that organization that trust is low, there is not discipline in works. Low level of trust makes remove the open communication and relations and leads to low quality decisions. In higher education institution, employees avoid expressing their idea, because they fear that their plans face failure (Cannon \& Edmondson, 2005). Moreover, the trust not only effect on quality but also can effect on performance, efficiency and effectiveness (Zamanan et al., 2020).

Organizational trust has been a steadily growing topic in the area of management and higher education institution and organization behavior. With time, scholars have shifted the attention to trust as an important organizational resource that has been shown to influence in a positive way work engagement, team commitment, cooperation and teamwork (Diener, Thapa, \& Tay, 2019), servant leadership (Cashman, 2017), and organizational culture (Lakuma et 
al., 2017). Therefore, this growing body of research refers both to individual, team and organizational level outcomes.

\subsection{Organizational Culture}

The concept of organizational culture showed progressive evolution in the mid-20th century and ever since then, authors have proposed several definitions of the concept, with the commonality among them being organizational culture comprises the values, beliefs, and assumptions shared or relayed among the members of the organization (Schein, 2010). Organizational culture represents the collective values, beliefs, and principles of organizational members and is a product of such factors as history, product, market, technology, and strategy, type of employees, management style, and national culture (Lukas, Whitwell \& Heide, 2013). Furthermore, Shalley and Christina (2004) indicate that culture is a salient social contextual factor that helps employees make sense of their environment and directs their attention to facets of organizational functioning that are valued, rewarded, and supported.

An organisation includes an entity that contains countless individuals and is established by groups of individuals as an attempt to attain impacts that cannot be achieved with one individual. As reported by Maduenyi et al, (2015) better outcomes are attainable from hierarchical effect directing organisation to attain certain organisational goals and trust by creating an acceptable culture from the viewpoint of all employees. The culture includes the generation of talent, leadership, functional relationships and arrangement (Lakuma et al., 2017). Researchers indicate that organizational culture has direct effect with organizational trust (e.g. e.g. Alston \& Tippett, 2009; Huff \& Kelley, 2005; Nadi, 2018). Figure 1 shows the research model of this study.

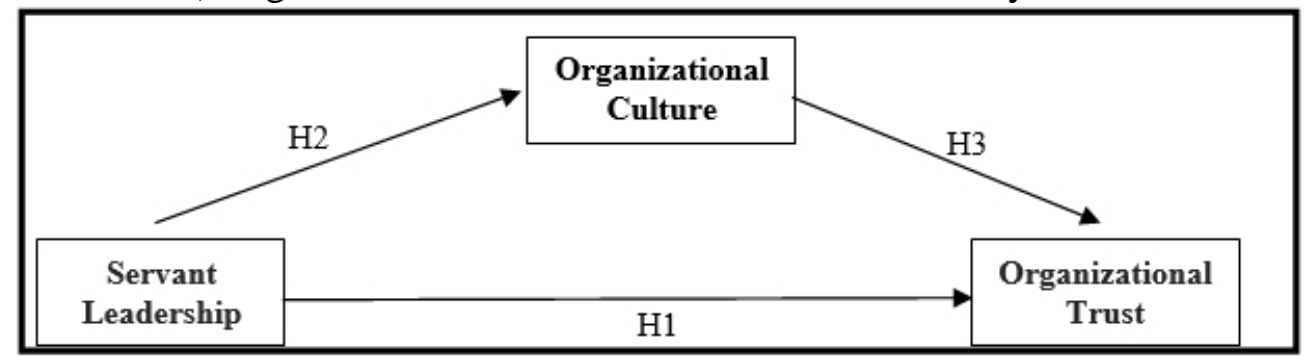

Figure 1 : Research Model

Aligned with the present study's objectives and the reviewed literature, this study proposed the following hypotheses to be tested:

Hypothesis 1: Servant leadership has a significant impact on organizational trust in Kuwaiti Ministry of Higher Education.

Hypothesis 2: Servant leadership has a significant impact on organizational culture in Kuwaiti Ministry of Higher Education. 
Hypothesis 3: Organizational culture has a significant impact on organizational trust in Kuwaiti Ministry of Higher Education.

Hypothesis 4: Organizational culture mediates the relationship between servant leadership and organizational trust in Kuwaiti Ministry of Higher Education.

\section{Research Methodology}

\subsection{Research Design and Sample}

This study used a survey questionnaire to examine the impact of servant leadership on organizational trust. The study also examines the mediating role of organizational culture for the mentioned relationship. Hayes (2017) indicated that there are many benefits associated with this method of data gathering. Firstly, this instrument of data gathering enables the researcher to exhaustively summarize the attitudes, thoughts as well as the behavior of the sample. At the same time, considering that these self-administered questionnaires being distributable to a significant number of respondents. Second, can also be sent via email, this method is efficient in terms of cost and time. Thirdly, the distribution of questionnaires is simple to do, and therefore, it is less prone to errors. Lastly, questionnaires support anonymity, and thus, the respondents would feel sufficiently comfortable in expressing their opinions as well as experiences.

The study population consists of the employees of the Kuwaiti Ministry of Higher Education, which amounted to 1101 employees (Kuwaiti Ministry of Higher Education, 2019). According to Sekaran and Bougie (2016), it is appropriate to obtain a sample of 285 respondents for a population amounted to 1100. A total of 285 questionnaires were distributed among the Kuwaiti Ministry of Higher Education employees. In total, 248 valid questionnaires to analysis were returned equivalent to $87 \%$ response rate. In particular, a minimum adequate response rate in survey studies is $30 \%$ (Sekaran \& Bougie, 2016). Therefore, the study response rate is highly adequate for further analysis.

\subsection{Measurements of Study}

Servant leadership was measured using a scale of Ehrhart (2004) in 14 items (e.g. "My supervisor creates a sense of community among department employees"). Organizational culture was measured using a scale of Hofstede, Neuijen, Ohayv, and Sanders (1990) in 12 items (e.g. "Good relations prevail among employees in the ministry"). Organizational trust was measured using a scale of Gabarro and Athos (1978) in 7 items (e.g. "I believe my employer has high integrity"). All variables have been measured using a 5-point Likert scale. 


\section{Data Analysis and Results}

The analysis of this study data included two main aspects namely measurement model assessment and structural model assessment using the software SmartPLS (version 3.3.2). Regarding the measurement model assessment, accurate procedures were followed to prove the validity and reliability of the measurement model, where the measurement model assessment included convergent validity and discriminant validity. Table 1 shows the results of convergent validity, where the results indicate that Cronbach's alpha and composite reliability achieved values greater than the proposed threshold values of 0.60 and above for all constructs (Hair, Hult, Ringle \& Sarstedt, 2016). Meanwhile, the results indicate also that the average variance extracted achieved values greater than the proposed threshold values of 0.50 and above for all constructs (Hair et al., 2016). Regarding factors loading, items have loading less than 0.4 were deleted (SL3: 0.167; SL8: 0.054; OC11: 0.236; OT7: 0.095), while other items were retained which ranged 0.687 to 0.885 based on recommendations of Hair et al. (2016).

Table 1: Convergent Validity

\begin{tabular}{|c|c|c|c|c|c|}
\hline Construct & Items & Loadings & Cronbach's Alpha & Composite Reliability & AVE \\
\hline \multirow{12}{*}{ Servant Leadership } & SL1 & 0.701 & 0.940 & 0.948 & 0.606 \\
\hline & SL2 & 0.848 & & & \\
\hline & SL4 & 0.754 & & & \\
\hline & SL5 & 0.721 & & & \\
\hline & SL6 & 0.818 & & & \\
\hline & SL7 & 0.698 & & & \\
\hline & SL9 & 0.885 & & & \\
\hline & SL10 & 0.838 & & & \\
\hline & SL11 & 0.760 & & & \\
\hline & SL12 & 0.804 & & & \\
\hline & SL13 & 0.791 & & & \\
\hline & SL14 & 0.695 & & & \\
\hline \multirow{11}{*}{ Organizational Culture } & $\mathrm{OC} 1$ & 0.733 & 0.933 & 0.940 & 0.590 \\
\hline & $\mathrm{OC} 2$ & 0.812 & & & \\
\hline & OC3 & 0.793 & & & \\
\hline & $\mathrm{OC} 4$ & 0.809 & & & \\
\hline & OC5 & 0.774 & & & \\
\hline & OC6 & 0.752 & & & \\
\hline & OC7 & 0.818 & & & \\
\hline & OC8 & 0.798 & & & \\
\hline & OC9 & 0.700 & & & \\
\hline & OC10 & 0.762 & & & \\
\hline & $\mathrm{OC} 12$ & 0.687 & & & \\
\hline \multirow{6}{*}{ Organizational Trust } & OT1 & 0.753 & 0.901 & 0.924 & 0.669 \\
\hline & OT2 & 0.811 & & & \\
\hline & OT3 & 0.829 & & & \\
\hline & OT4 & 0.833 & & & \\
\hline & OT5 & 0.821 & & & \\
\hline & OT6 & 0.858 & & & \\
\hline
\end{tabular}


The next step to measurement model assessment was discriminant validity. Fornell-Larcker Criteria and Heterotrait-Monotrait Ratio (HTMT) were used to assessment of discriminant validity. Table 2 shows the results of discriminant validity based on Fornell-Larcker Criteria, where that values for each construct (in bold) is higher than the other items of the row and column in which they are located. Thus, this study has discriminant validity (Henseler, Hubona \& Ray, 2016).

Table 2: Discriminant Validity Based on Fornell-Larcker Criteria

\begin{tabular}{lccc}
\hline Construct & $\begin{array}{c}\text { Servant } \\
\text { Leadership }\end{array}$ & $\begin{array}{c}\text { Organizational } \\
\text { Culture }\end{array}$ & $\begin{array}{c}\text { Organizational } \\
\text { Trust }\end{array}$ \\
\hline $\begin{array}{l}\text { Servant } \\
\begin{array}{l}\text { Leadership } \\
\text { Organizational }\end{array}\end{array}$ & $\mathbf{0 . 7 7 8}$ & & \\
$\begin{array}{l}\text { Culture } \\
\text { Organizational } \\
\text { Trust }\end{array}$ & 0.183 & $\mathbf{0 . 7 6 8}$ & \\
\hline
\end{tabular}

Regarding the Heterotrait-Monotrait Ratio (HTMT), Table 3 shows the results of discriminant validity based on Heterotrait-Monotrait Ratio (HTMT), where the results indicate that Heterotrait-Monotrait Ratio (HTMT) achieved values smaller than the proposed threshold values of 0.85 and below for all constructs (Kline, 2015). Therefore, the measurement model in this study are valid and reliable based on previous results.

Table 3: Discriminant Validity Based on Heterotrait-Monotrait Ratio (HTMT)

\begin{tabular}{lccc}
\hline Construct & $\begin{array}{c}\text { Servant } \\
\text { Leadership }\end{array}$ & $\begin{array}{c}\text { Organizational } \\
\text { Culture }\end{array}$ & $\begin{array}{c}\text { Organizational } \\
\text { Trust }\end{array}$ \\
\hline $\begin{array}{l}\text { Servant } \\
\text { Leadership }\end{array}$ & & & \\
$\begin{array}{l}\text { Organizational } \\
\text { Culture }\end{array}$ & 0.169 & & \\
$\begin{array}{l}\text { Organizational } \\
\text { Trust }\end{array}$ & 0.569 & 0.292 & \\
\hline
\end{tabular}

After assessing the validity and reliability of the measurement model has been confirmed, the next step was a structural model assessment by examining the standardized path coefficients in order to test the hypothesized relationships among the constructs. Figure 2 shows the results of path coefficients using PLS Algorithm. 


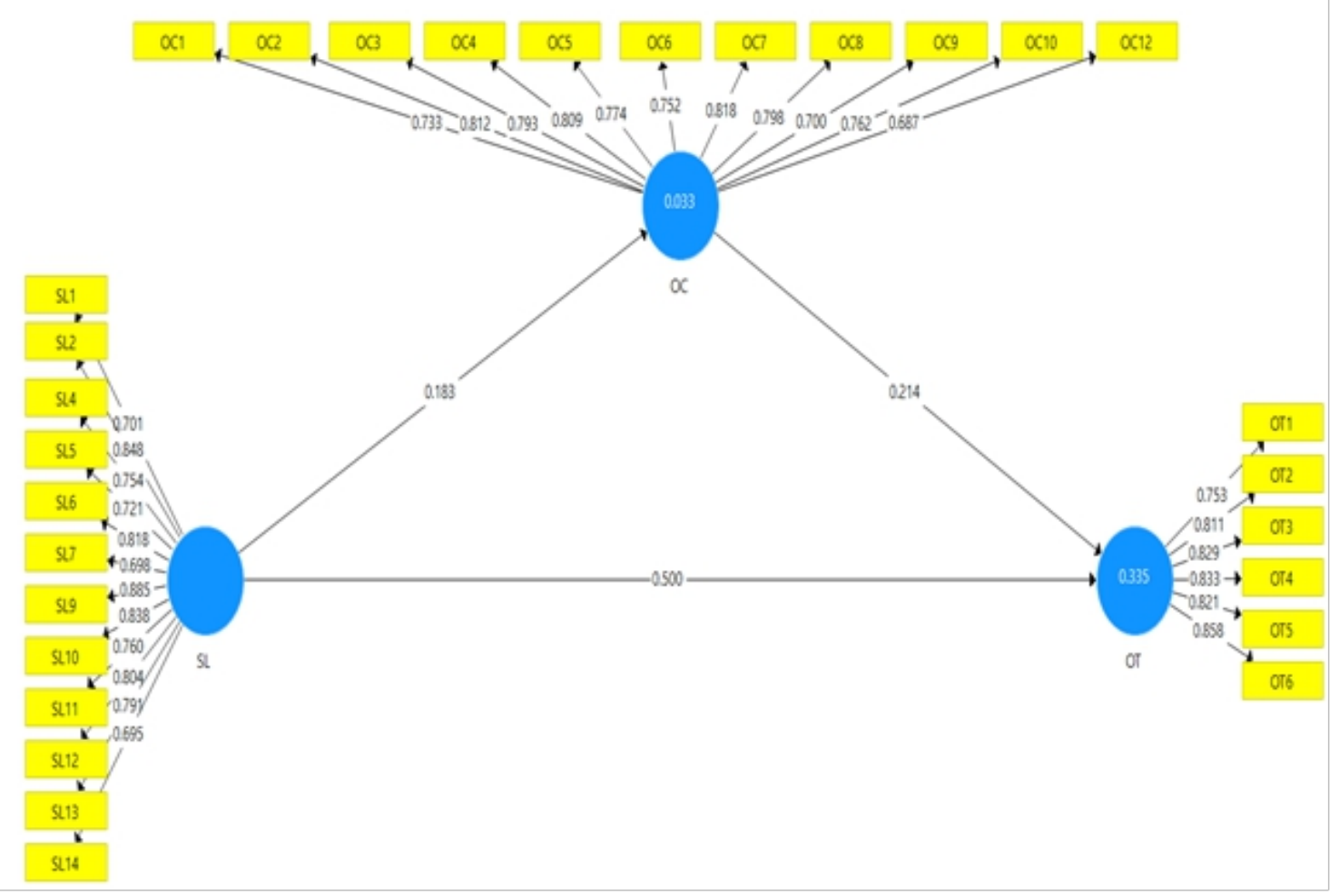

Figure. 2 Results of path coefficients using PLS Algorithm

The technique of bootstrapping embedded with SmartPLS (version 3.3.2) was used to confirm if the path coefficients are insignificant or significant. Table 4 shows P-Values for each path coefficient.

Table 4: P-Values for each path coefficient

\begin{tabular}{lcccccccc}
\hline No. & Hypotheses & $\begin{array}{c}\text { Path } \\
\text { Coefficient }\end{array}$ & $\begin{array}{c}\text { Standard } \\
\text { Deviation }\end{array}$ & T-Value & P-Value & \multicolumn{2}{c}{ Confidence Interval } & Decision \\
\cline { 6 - 7 } & & & & 95\% LL & 95\% UL & \\
\hline H1 & SL $\rightarrow$ OT & 0.500 & 0.050 & 10.064 & 0.000 & 0.397 & 0.593 & Supported*** \\
H2 & SL $\rightarrow$ OC & 0.183 & 0.057 & 3.191 & 0.001 & 0.046 & 0.278 & Supported** \\
H3 & OC $\rightarrow$ OT & 0.214 & 0.050 & 4.288 & 0.000 & 0.104 & 0.298 & Supported*** \\
\hline
\end{tabular}

Note: **: $\mathrm{p}<0.01, *: \mathrm{p}<0.05$

As indicated in Table 4, servant leadership has a positive direct impact on organizational trust in Kuwaiti Ministry of Higher Education (Path Coefficient $=0.500 ; \mathrm{T}-$ Value $=10.064 ; \mathrm{P}-$ Value $=0.000)$, therefore H1 was supported. This finding was compatible with many previous studies (e.g. Nyhan, 2000; Sendjaya \& Sarros, 2002; Rezaei et al., 2012), who indicated that trust is one of the important indicators to servant leadership. Through servant Leadership approach, qualified employees will perform at a high level, 
they will feel more important to their work and will find stronger motivations to rise to their level of practical, intellectual and skill level, which in turn leads to the organization's ability to reach the goals it seeks. In addition, the servant leadership approach contributes to reducing business-related costs, welltrained, and highly skilled staff will continue to work in the organization as a result of their sense of increased trust.

The findings also indicated that servant leadership has a positive direct impact on organizational culture in Kuwaiti Ministry of Higher Education (Path Coefficient $=0.183 ; \mathrm{T}-$ Value $=3.191 ; \mathrm{P}-$ Value $=0.001)$, therefore $\mathrm{H} 2$ was supported. This finding was compatible with many previous studies (e.g. Harwiki, 2016; Setyaningrum, 2017; Sihombing et al., 2018), who indicated that servant leadership thinks about the needs of employees by acknowledging the views of others and giving them the support they need to achieve their work and goals their organization and involve them in making decisions when needed. In addition, the servant leadership approach contributes to building a sense of unity and harmony within the team, which ultimately contributes to building a supportive culture for employees in the work environment. Therefore, managers and decision-makers in the Kuwaiti Ministry of Higher Education should help employees by creating an environment where they can freely state their difficulties.

The findings also indicated that organizational culture has a positive direct impact on organizational trust in Kuwaiti Ministry of Higher Education (Path Coefficient $=0.214 ; \mathrm{T}-$ Value $=4.288 ; \mathrm{P}-$ Value $=0.000)$, therefore $\mathrm{H} 1$ was supported. This finding was compatible with many previous studies (e.g. Alston \& Tippett, 2009; Huff \& Kelley, 2005; Nadi, 2018), who indicated that by set the organizational culture and values, organizations can strengthen the image, profit, employee motivation, and commitment are strengthened as a result of a high level of trust. In addition, strengthening of trust as a part of organizational culture provides certain benefits like efficiency, commitment, innovation, outcomes, and motivation.

This study suggested that organizational culture mediates the relationship between servant leadership and organizational trust in the Kuwaiti Ministry of Higher Education. Table 5 shows testing the mediating effect of organizational culture using the bootstrap method (Preacher \& Hayes, 2008). As indicated in Table 5, that organizational culture partially mediated the relationship between servant leadership and organizational trust. This result indicates that a portion of the impact of servant leadership on organizational trust is mediated through organizational culture, whereas servant leadership still explains a portion of organizational trust. According to servant leadership theory, a servant leader is a person interested in his followers' benefits compare to his benefit (Greenleaf, 2002). Therefore, the concept of servant leadership has this ability that can improve organizations and employees', 
which contributes to enhancing the culture and trust of both employees and organizations as a whole.

Table 5: Testing the Mediating Effect of Organizational Culture

\begin{tabular}{cccccccc}
\hline No. & Hypothesis & $\begin{array}{c}\text { Indirect } \\
\text { Effect }\end{array}$ & $\begin{array}{c}\text { Standard } \\
\text { Deviation }\end{array}$ & P-value & \multicolumn{2}{c}{ Confidence Interval } & Decision \\
\hline H4 & SL $\rightarrow \mathrm{OC} \rightarrow \mathrm{OT}$ & 0.039 & 0.016 & 0.015 & 0.012 & 0.070 & Partial Mediation \\
\hline
\end{tabular}

\section{Conclusion}

This study aims to examine the impact of servant leadership on organizational trust and the mediating role of organizational culture for the mentioned relationship. The results of this study indicated that there is a positive impact of servant leadership and organizational culture on organizational trust for employees in the Kuwaiti Ministry of Higher Education. As results indicated to a positive impact of servant leadership on organizational culture for employees in the Kuwaiti Ministry of Higher Education. Therefore, servant leadership contributes to enhance and support the culture and trust of employees significantly, where that servant leadership thinks about the needs of employees by acknowledging the views of others and giving them the support they need to achieve their work and goals their organization and involve them in making decisions when needed. In addition, the servant leadership approach contributes to building a sense of unity and harmony within the team, which ultimately contributes to enhance and support the culture and trust of employees in the work environment. In addition, by increase interest to the organizational culture of employees, the organizations can strengthen the motivation and commitment of employees as a result of a high level of trust.

Moreover, organizational culture partially mediated the relationship between servant leadership and organizational trust for employees in the Kuwaiti Ministry of Higher Education. This result indicates that a portion of the impact of servant leadership on organizational trust is mediated through organizational culture, whereas servant leadership still explains a portion of organizational trust. The servant leadership theory supports this relationship, because the concept of servant leadership has an ability that can improve organizations and employees', which contributes to enhancing the culture and trust of both employees and organizations as a whole. This study was limited to employees in the Kuwaiti Ministry of Higher Education as a sample. Future studies may include examining this model in other sectors such as the health care sector, banking sector, or industrial sector. Moreover, taking a longitudinal approach instead of a cross-sectional approach may be more beneficial to obtain more rich data, which contributes to a more comprehensive description of the phenomenon. 


\section{References:}

1. Aburumman, O., Salleh, A., Omar, K., \& Abadi, M. (2020). The impact of human resource management practices and career satisfaction on employee's turnover intention. Management Science Letters, 10(3), 641-652.

2. Alown, B. E., Mohamad, M. B., \& Karim, F (2020). Structural Equation Modelling Based Empirical Analysis: Direct and Indirect Effects of Job Satisfaction on Job Performance in Jordanian Five-Star Hotels. Environment, 5(18), 133-151.

3. Alston, F., \& Tippett, D. (2009). Does a technology-driven organization's culture influence the trust employees have in their managers?. Engineering Management Journal, 21(2), 3-10.

4. Asencio, H., \& Mujkic, E. (2016). Leadership behaviors and trust in leaders: Evidence from the US federal government. Public Administration Quarterly, 156-179.

5. Balkan, M. O., Serin, A. E., \& Soran, S. (2014). The relationship between trust, turnover intentions and emotions: An application. European Scientific Journal, 10(2).

6. Belias, D., \& Koustelios, A. (2014). The impact of leadership and change management strategy on organizational culture. European Scientific Journal, 10(7), 451-470.

7. Blanchard, K. (2018). Leading at a higher level: Blanchard on leadership and creating high performing organizations. FT Press.

8. Cannon, M. D., \& Edmondson, A. C. (2005). Failing to learn and learning to fail (intelligently): How great organizations put failure to work to innovate and improve. Long range planning, 38(3), 299-319.

9. Cashman, K. (2017). Leadership from the inside out: Becoming a leader for life. Berrett-Koehler Publishers.

10. Chen, Y. C. (2017). The relationships between brand association, trust, commitment, and satisfaction of higher education institutions. International Journal of Educational Management, 31(7), 973-985.

11. Dennis, R. S., (2004). Servant Leadership Theory, Assessment Instrument. A Dissertation presented in Partial fulfillment of the requirement for the degree Doctor of Philosophy.

12. Diener, E., Thapa, S., \& Tay, L. (2019). Positive Emotions at Work. Annual Review of Organizational Psychology and Organizational Behavior, 7.

13. Ehrhart, M. G. (2004). Leadership and procedural justice climate as antecedents of unit-level organizational citizenship behavior. Personnel Psychology, 57(1), 61-94.

14. El Mallakh, R. (2019). Kuwait: Trade and Investment. Routledge. 
15. Eva, N., Robin, M., Sendjaya, S., van Dierendonck, D., \& Liden, R. C. (2019). Servant leadership: A systematic review and call for future research. The Leadership Quarterly, 30(1), 111-132.

16. Ferres, N., Connell, J., \& Travaglione, A. (2004). Co-worker trust as a social catalyst for constructive employee attitudes. Journal of Managerial Psychology, 19(6), 608-622.

17. Gabarro, J. Athos, P. (1978). Interpersonal relations and communications. Prentice-Hall: New York, NY, USA.

18. Gandolfi, F., Stone, S., \& Deno, F. (2017). Servant leadership: An ancient style with 21 st century relevance. Revista de Management Comparat International, 18(4), 350-361.

19. Greenleaf, R. K. (2002). Servant leadership: A journey into the nature of legitimate power and greatness. Paulist Press.

20. Hair Jr, J. F., Hult, G. T. M., Ringle, C., \& Sarstedt, M. (2016). A primer on partial least squares structural equation modeling (PLSSEM). Sage publications.

21. Harwiki, W. (2016). The impact of servant leadership on organization culture, organizational commitment, organizational citizenship behaviour (OCB) and employee performance in women cooperatives. Procedia-Social and Behavioral Sciences, 219(1), 283290.

22. Hayes, A. F. (2017). Introduction to mediation, moderation, and conditional process analysis: A regression-based approach. Guilford publications.

23. Henseler, J., Hubona, G., \& Ray, P. A. (2016). Using PLS path modeling in new technology research: updated guidelines. Industrial management \& data systems.

24. Hofstede, G., Neuijen, B., Ohayv, D. D., \& Sanders, G. (1990). Measuring organizational cultures: A qualitative and quantitative study across twenty cases. Administrative science quarterly, 35(2), 286-316.

25. Huff, L., \& Kelley, L. (2005). Is collectivism a liability? The impact of culture on organizational trust and customer orientation: a sevennation study. Journal of business research, 58(1), 96-102.

26. Indiya, G. D., Obura, J., \& Mise, J. K. (2018). Effect of Organization Culture on organization performance on Public Universities in Kenya. European Scientific Journal, 14(19), 15-35.

27. Kiker, D. S., Callahan, J. S., \& Kiker, M. B. (2019). Exploring the boundaries of servant leadership: A meta-analysis of the main and moderating effects of servant leadership on behavioral and affective outcomes. Journal of Managerial Issues, 31(2), 172-117. 
28. Kline, R. B. (2015). Principles and practice of structural equation modeling. Guilford publications.

29. Kurnaz, G. (2018). A Research on the Relationship between Servant Leadership and Organizational Trust. Journal of Institute of Economic Development and Social Researches, 4(11),505-521.

30. Kuwaiti Ministry of Higher Education. (2019). Retrieved July 18, 2019, from https://www.mohe.edu.kw/site/ar/info-center/orgstructure.aspx.

31. Lakuma, C. P., Katunze, M., Nagawa, M., Mawejje, J., Lwanga, M., Mbowa, S., \& Shinyekwa, I. (2017). Country Reviews of Capacity Development: The Case of Uganda (No. 674-2017-1128).

32. Lemoine, G. J., Hartnell, C. A., \& Leroy, H. (2019). Taking stock of moral approaches to leadership: An integrative review of ethical, authentic, and servant leadership. Academy of Management Annals, 13(1), 148-187.

33. Lukas, B. A., Whitwell, G. J., \& Heide, J. B. (2013). Why do customers get more than they need? How organizational culture shapes product capability decisions. Journal of Marketing, 77(1), 1-12.

34. Maduenyi, M. (2015). Foreign artisans take over Nigeria's construction industry. Viewed from: http://www. punchng. $\mathrm{com} /$ special-feature/foreign-artisans-take-over-nigeriasconstructionindustry/. Accessed on, 13(08), 2015.

35. Matteson, J. A., \& Irving, J. A. (2006). Servant versus self-sacrificial leadership: A behavioral comparison of two follow-oriented leadership theories. International Journal of Leadership Studies, 2(1), 36-51.

36. Nadi, M. A. (2018). The structural model of relationship between organizational trust and organizational commitmen with knowledge sharing behavior: The mediation of organizational culture and organizational Health Teachers. Journal of new approach in educational administration, 9 (3), 291-310.

37. Nyhan, R. C. (2000). Changing the paradigm: Trust and its role in public sector organizations. The American Review of Public Administration, 30(1), 87-109.

38. Pierce, J. L., \& Newstrom, J. W. (2003). Leaders \& the leadership process. McGraw-Hill/Irwin.

39. Preacher, K. J., \& Hayes, A. F. (2008). Asymptotic and resampling strategies for assessing and comparing indirect effects in multiple mediator models. Behavior research methods, 40(3), 879-891.

40. Reid, R. D., \& Sanders, N. R. (2019). Operations management: an integrated approach. John Wiley \& Sons.

41. Rezaei, M., Salehi, S., Shafiei, M., \& Sabet, S. (2012). Servant Leadership and Organizational Trust: The Mediating Effect of the 
Leader Trust and Organizational Communication. Emerging Markets Journal, 2(1), 70-78.

42. Salama, I. K. Y. (2018). The Relationship between Organizational Culture and Administrative Creativity in Universities. European Scientific Journal, 14(4), 146.

43. Schein, E. H. (2010). Organizational culture and leadership (Vol. 2). John Wiley \& Sons.

44. Sekaran, U., \& Bougie, R. (2016). Research methods for business: A skill building approach. John Wiley \& Sons.

45. Sendjaya, S., \& Sarros, J. C. (2002). Servant leadership: Its origin, development, and application in organizations. Journal of Leadership \& Organizational Studies, 9(2), 57-64.

46. Setyaningrum, R. P. (2017). Relationship between servant leadership in organizational culture, organizational commitment, organizational citizenship behaviour and customer satisfaction. European Research Studies Journal, 3A, 554-569.

47. Shalley, C. E., \& Gilson, L. L. (2004). What leaders need to know: A review of social and contextual factors that can foster or hinder creativity. The leadership quarterly, 15(1), 33-53.

48. Shockley-Zalabak, P., Ellis, K., \& Winograd, G. (2000). Organizational trust: What it means, why it matters. Organization Development Journal, 18(4), 35-48.

49. Sihombing, S., Astuti, E. S., Al Musadieq, M., Hamied, D., \& Rahardjo, K. (2018). The effect of servant leadership on rewards, organizational culture and its implication for employee's performance. International Journal of Law and Management.

50. Vanhala, M., Heilmann, P., \& Salminen, H. (2016). Organizational trust dimensions as antecedents of organizational commitment. Knowledge and Process Management, 23(1), 46-61.

51. Zamanan, M., Alkhaldi, M., Almajroub, A., Alajmi, A., Alshammari, J., \& Aburumman, O. (2020). The influence of HRM practices and employees' satisfaction on intention to leave. Management Science Letters, 10(8), 1887-1894. 